\title{
Centipedes (Myriapoda, Chilopoda) of Biologia Centrali-Americana: Current status of the names
}

\author{
Fabio Germán Cupul-Magańa \\ Centro Universitario de la Costa, Universidad de Guadalajara, Av. Universidad de Guadalajara No. 203, \\ Delegación Ixtapa, C.P. 48280, Puerto Vallarta, México. \\ Corresponding author: Cupul-Magaña FG (abio_cupul@yahoo.com.mx)
}

Academic editor: Pavel Stoev | Received 28 July 2011 | Accepted 20 September 2011 | Published 11 October 2011

Citation: Cupul-Magaña FG (2011) Centipedes (Myriapoda, Chilopoda) of Biologia Centrali-Americana: Current status of the names. International Journal of Myriapodology 5: 55-62. doi: 10.3897/ijm.5.1865

\begin{abstract}
For the last 100 years, Biologia Centrali-Americana has been an important source of information for many groups of Mexican and Central American arthropods and remains a keystone for taxonomic work. However, many included names are now out of date. I provide an updated list of names of Chilopoda as cited in Vol. 14 of Biologia Centrali-Americana to use as a complement to that work. The Chilopoda of Biologia Centrali-Americana included 52 names for 51 species and 1 subspecies. Of those, 18 names (35\%) were described as new in Pocock's work. Currently 24 remain as valid names in the same genus, 17 have been transferred to other genera and 11 have been treated as synonyms.
\end{abstract}

\section{Keywords}

Central America, Checklist, Chilopoda, Mexico, Reginald Innes Pocock, Taxonomy

\section{Introduction}

Biologia Centrali-Americana is one of the greatest works on the natural history of Mexico and Central America. The project, edited by Frederick DuCane Godman and Osbert Salvin, opened in 1879 with sections on Mammalia, Aves and Botany. The entire work was published between 1879-1915, and contains 215 parts on Zoology, 
25 on Botany, and 17 on Archaeology, grouped in 63 volumes and accompanied by numerous plates of figures (Navarrete-Heredia et al. 2006).

For the last 100 years, Biologia Centrali-Americana has been an important source of information for many groups of Mexican and Central American arthropods (Morón 1994) and remains a keystone for taxonomic work (Navarrete-Heredia et al. 2006). This is the case of non-insect arthropods (Arachnida, Chilopoda and Diplopoda), which are represented in this classic work by 1560 species (Llorente-Bousquets et al. 1996). Selander and Vaurie (1962) described Biologia Centrali-Americana a an incomparable contribution to the study of the natural history of the New World, that did much to lay the foundation for the study of the biogeography of this area.

For many years, the availability of Biologia Centrali-Americana was restricted to larger museums and libraries around the world. Recently, as part of joint efforts by the Natural History Museum in London and the National Museum of Natural History in Washington, D. C., all contents were made available free on the internet at: http:// www.sil.si.edu/DigitalCollections/bca/ (Navarrete-Heredia et al. 2006). The University of Michigan joined in these efforts to help create reprinted copies reproduced directly from unreviewed and unedited digital scans made from a copy from the library collection (http://www.lib.umich.edu).

The availability of this information facilitates and promotes its use in taxonomic research, especially for those researchers interested in the centipedes. However the names of taxa described or cited in Biologia Centrali-Americana are now a century of more out of date and numerous changes in generic and species concepts have been made during that time (Navarrete-Heredia et al. 2006). Although Chilobase, a web resource for Chilopoda Taxonomy (http://chilobase.bio.unipd.it/), catalogued and updated all known centipede species of the world (Minelli et al. 2006), it did not display a list with current names from Biologia Centrali-Americana. For this reason, the aim of this paper is provide a complete list of current status of all Chilopoda names cited in Biologia Centrali-Americana to stimulate further taxonomic research and avoid confusion.

\section{Materials and methods}

All scientific names of Chilopoda cited by Pocock in Vol. 14 (1895-1910) of Biologia Centrali-Americana are recorded below in checklist format. The information incorporated in this checklist includes the number of the page where the name is cited in Pocock's work, as well as the genus and species. The checklist was completed with author and year of each name, current order and family in which the species is placed and the current valid name.

For the assignment of the current valid names for each species, the latest taxonomic scrutiny reference was reviewed. I follow the works of Verhoeff (1925), Attems (1930), Bücherl (1942, 1974), Chamberlin (1943), Eason (1972, 1973), Würmli (1973, 2005), Koch (1985), Shelley (1997, 2006), Schileyko and Minelli (1999), Foddai et al. (2000), Lewis (2002), Chagas-Junior (2003, 2010), Chagas- 
Junior and Shelley (2003), Schileyko and Stagl (2004), Shelley and Chagas-Junior (2004), Edgecombe and Giribet (2009), Edgecombe (2011), and Edgecombe and Bonato (2011). Also, all current valid names were checked with the use of the online database Chilobase (Minelli et al. 2006).

The Chilopoda of Biologia Centrali-Americana included 52 names for 51 species and 1 subspecies. Of those, 18 names (35\%) were described as new in Pocock's work. Currently 24 remain as valid names in the same genus, 17 have been previously transferred to other genera and 11 have been treated as synonyms.

List of the Chilopoda species described or cited in Pocock (1895-1910), Chilopoda and Diplopoda, in Vol. 14 of Biologia Centrali-Americana is shown below. Species names are organized by page number in Pocock's work (in bold at left) and then in the sequence they appear on the page. Names in italics are as cited in the volume; bold names indicate the current valid name for each cited species, followed by its author and year, and (in brackets) by a recent reference showing this status. The order and family name at left indicates the current placement of the species.

\section{SCUTIGEROMORPHA Pocock, 1895}

\section{Scutigeridae Gervais, 1837}

1 Scutigera linceci (Wood, 1867): Dendrotherena linceci (Wood, 1867) (Würmli 1973; Edgecombe and Giribet 2009; Edgecombe 2011)

\section{Pselliodidae Chamberlin, 1921}

2 Scutigera nigro-vittata Meinert, 1886: Sphendononema guildingii (Newport, 1845) (Würmli 2005)

\section{LITHOBIOMORPHA Pocock, 1895}

\section{Lithobiidae Newport, 1844}

4 Lithobius macroceros Pocock, 1895: Sotimpius macroceros (Pocock, 1895) (Eason 1973)

5 Lithobius pontifex Pocock, 1895: Guerrobius pontifex (Pocock, 1895) (Eason 1973)

5 Lithobius humberti Pocock, 1895: Guerrobius humberti (Pocock, 1895) (Eason 1973)

6 Lithobius godmani Pocock, 1895: Vulcanbius godmani (Pocock, 1895) (Eason 1973)

7 Lithobius salvini Pocock, 1895: Vulcanbius salvini (Pocock, 1895) (Eason 1973)

8 Lithobius vulcani Pocock, 1895: Vulcanbius vulcani (Pocock, 1895) (Eason 1973)

9 Lithobius decodontus Pocock, 1895: Lithobius decodontus Pocock, 1895 (Eason 1973)

9 Lithobius stolli Pocock, 1895: Lithobius castaneus Newport, 1844 (Eason 1972)

10 Lithobius aztecus Humbert \& Saussure, 1869: Neolithobius aztecus (Humbert \& Saussure, 1869) (Chamberlin 1943) 
10 Lithobius mystecus Humbert \& Saussure, 1869: Lithobius mystecus Humbert \& Saussure, 1869 (Verhoeff 1925)

11 Lithobius toltecus Humbert \& Saussure, 1869: Lithobius toltecus Humbert \& Saussure, 1869 (Verhoeff 1925)

12 Lithobius saussurei Stuxberg, 1875: Lithobius saussurei Stuxberg, 1875 (Verhoeff 1925)

12 Lithobius mexicanus Perbosc, 1839: Lithobius mexicanus Perbosc, 1839 (Verhoeff 1925)

SCOLOPENDROMORPHA Pocock, 1895

Scolopendridae Newport, 1844

14 Scolopendra morsitans Linnaeus, 1758: Scolopendra morsitans Linnaeus, 1758 (Shelley 2006)

14 Scolopendra subspinipes Leach, 1815: Scolopendra subspinipes Leach, 1815 (Shelley 2006)

14 Scolopendra gigas Leach, 1815: Scolopendra gigantea Linnaeus, 1758 (Shelley 2006)

15 Scolopendra pygmaea Pocock, 1895: Arthrorbabdus pygmaeus (Pocock, 1895) (Shelley and Chagas-Junior 2004)

15 Scolopendra pomacea C. L. Koch, 1847: Scolopendra pomacea C. L. Koch, 1847 (Shelley 2006)

17 Scolopendra punctiventris Newport, 1844: Hemiscolopendra marginata (Say, 1821) (Shelley 2006)

18 Scolopendra tenuitarsis Pocock, 1895: Scolopendra viridis Say, 1821 (Shelley 2006)

18 Scolopendra heros Girard, 1853: Scolopendra heros Girard, 1853 (Shelley 2006)

19 Scolopendra copeana Wood, 1862: Scolopendra polymorpha Wood, 1861 (Shelley 2006)

20 Scolopendra copeana gaumeri Pocock, 1895: Scolopendra polymorpha Wood, 1861 (Shelley 2006)

20 Scolopendra sumichrasti Saussure, 1860: Scolopendra sumichrasti Saussure, 1860 (Shelley 2006)

21 Scolopendra viridis Say, 1821: Scolopendra viridis Say, 1821 (Shelley 2006)

23 Scolopendra pachygnatha Pocock, 1895: Scolopendra pachygnatha Pocock, 1895 (Shelley 2006)

24 Scolopendra occidentalis Meinert, 1886: Scolopendra viridis maya Saussure, 1860 (Shelley 2006)

24 Scolopendra nicaraguensis Bollman, 1893: Scolopendra viridis Say, 1821 (Shelley 2006)

24 Cormocephalus aurantiipes (Newport, 1844): Cormocephalus aurantiipes (Newport, 1844) (Schileyko and Stagl 2004) 
25 Parotostigmus denticulatus Pocock, 1896: Otostigmus (Parotostigmus) denticulatus Pocock, 1896 (Bücherl 1942)

26 Rhysida immarginata (Porat, 1876): Rhysida immarginata (Porat, 1876) (Koch 1985)

27 Rhysida celeris (Humbert \& Saussure, 1870): Rhysida celeris (Humbert \& Saussure, 1870) (Bücherl 1974)

27 Rhysida longipes (Newport, 1845): Rhysida longipes (Newport, 1845) (Lewis 2002)

Plutoniumidae Bollman, 1893 (Edgecombe and Bonato 2011)

28 Theatops spinicauda Wood, 1862: Theatops spinicaudus Wood, 1862 (Shelley 1997)

\section{Scolopocryptopidae Pocock, 1896}

29 Otocryptops ferrugineus Pocock, 1893: Scolopocryptops ferrugineus Linnaeus, 1767 (Chagas-Junior 2003)

29 Otocryptops melanostoma Pocock, 1893: Scolopocryptops melanostoma (Newport, 1845) (Chagas-Junior 2010)

30 Scolopendrides mexicanus Saussure, 1858: Newportia mexicana (Saussure, 1858) (Chagas-Junior and Shelley 2003)

31 Scolopendrides stolli Pocock, 1896: Newportia stolli (Pocock, 1896) (Chagas and Shelley 2003)

32 Newportia azteca Humbert \& Saussure, 1869: Newportia azteca Humbert \& Saussure, 1869 (Chagas-Junior and Shelley 2003)

33 Newportia spinipes Pocock, 1896: Newportia spinipes Pocock, 1896 (Chagas and Shelley 2003)

34 Newportia rogersi Pocock, 1896: Newportia monticola Pocock, 1890 (Schileyko and Minelli 1999; Chagas-Junior and Shelley 2003)

\section{GEOPHILOMORPHA Pocock, 1895}

\section{Geophilidae Cook, 1895}

36 Geophilus aztecus Humbert \& Saussure, 1869: Geophilus aztecus Humbert \& Saussure, 1869 (Foddai et al. 2000)

37 Geophilus toltecus Humbert \& Saussure, 1869: Polycricus toltecus (Humbert \& Saussure, 1869) (Foddai et al. 2000)

37 Geophilus godmani Pocock, 1896: Polycricus godmani (Pocock, 1896) (Foddai et al. 2000)

38 Geophilus salvini Pocock, 1896: Pachymerium salvini (Pocock, 1896) (Foddai et al. 2000)

38 Geophilus stolli Pocock, 1896: Polycricus stolli (Pocock, 1896) (Foddai et al. 2000) 
39 Chomatophilus smithi Pocock, 1896: Chomatophilus smithi Pocock, 1896 (Foddai et al. 2000)

\section{Himantariidae Cook, 1895}

40 Chomatobius mexicanus (Saussure, 1860): Chomatobius mexicanus (Saussure, 1860) (Foddai et al. 2000)

\section{Oryidae Cook, 1896}

40 Orphnaeus brevilabiatus (Newport, 1895): Orphnaeus brevilabiatus (Newport, 1895) (Foddai et al. 2000)

40 Notiphilides maximiliani Humbert \& Saussure, 1870: Notiphilides maximiliani Humbert \& Saussure, 1870 (Foddai et al. 2000)

\section{Acknowledgments}

I am grateful to Dr. Greg Edgecombe by the revision of the previous version of the manuscript. Valuable comments by two anonymous reviewers helped improve the quality of the paper.

\section{References}

Attems C (1930) Myriapoda. 2. Scolopendromorpha. Das Tierreich 54: 1-308.

Bücherl W (1942) Catálogo dos quilópodos da zona neotrópica. Memórias do Instituto Butan$\tan 15: 251-372$.

Bücherl W (1974) Die Scolopendromorpha der neotropischen Region. Symposia of the Zoological Society of London 32: 99-133.

Chagas-Junior A (2003) Revisão das espécies neotropicais de Scolopocryptopinae (Chilopoda: Scolopendromorpha: Scolopocryptopidae). MSc Thesis, Rio de Janeiro, Brazil: Universidade Federal do Rio de Janeiro.

Chagas-Junior A (2010) On Scolopocryptops species from Fiji Islands (Chilopoda, Scolopendromorpha, Scolopocryptopidae). International Journal of Myriapodology 3:159-168. doi: $10.1163 / 187525410 X 12578602960623$

Chagas-Junior A, Shelley RM (2003) The centipede genus Newportia Gervais, 1847, in Mexico: description of a new troglomorphic species; redescription of N. sabina Chamberlin, 1942; revival of $N$. azteca Humbert \& Saussure, 1869; and a summary of the fauna (Scolopendromorpha: Scolopocryptopidae: Newportiinae). Zootaxa 379: 1-20.

Chamberlin RV (1943) On Mexican centipeds. Bulletin of the University of Utah, Biological Series 7: $1-55$ 
Eason EH (1972) The type specimens and identity of the species described in the genus Lithobius by C. L. Koch and L. Koch from 1841 to 1878 (Chilopoda: Lithobiomorpha). Bulletin of the British Museum (Natural History), Zoology 22: 103-150.

Eason EH (1973) The type specimens and identity of the species described in the genus Lithobius by R. L. Pocock from 1890 to 1901 (Chilopoda Lithobiomorpha). Bulletin of the British Museum (Natural History), Zoology 25: 41-83.

Edgecombe GE (2011) Chilopoda - taxonomic overview: Order Scutigeromorpha. In: Minelli A (Ed) Anatomy, Taxonomy, Biology. The Myriapoda, Vol. 1. Brill, Leiden, 363-370.

Edgecombe GE, Bonato L (2011) Chilopoda - taxonomic overview: Order Scolopendromorpha. In: Minelli A (Ed) Anatomy, Taxonomy, Biology. The Myriapoda, Vol. 1. Brill, Leiden, 392-407. Edgecombe GE, Giribet G (2009) Phylogenetics of scutigeromorph centipedes (Myriapoda: Chilopoda) with implications for species delimitation and historical biogeography of the Australian and New Caledonian faunas. Cladistics 25: 406-427. doi: 10.1111/j.10960031.2009.00253.x

Foddai D, Pereira LA, Minelli A (2000) A catalogue of the geophilomorph centipedes (Chilopoda) from Central and South America including Mexico. Amazoniana 16 (1/2): 59-185.

Koch LE (1985) The taxonomy of Australian centipedes of the genus Rhysida Wood (Chilopoda: Scolopendridae: Otostigminae). Journal of Natural History 19: 205-214. doi: $10.1080 / 00222938500770151$

Lewis JGE (2002) The scolopendromorph centipedes of Mauritius and Rodrigues and their adjacent islets (Chilopoda: Scolopendromorpha). Journal of Natural History 36: 79-106. doi: 10.1080/00222930110098508

Llorente-Bousquets J, González E, García-Aldrete AN, Cordero C (1996) Breve panorama de la taxonomía de artrópodos en México. In: Llorente-Bousquest J, García-Aldrete AN, González-Soriano E (Eds) Biodiversidad, taxonomía y biogeografía de artrópodos de México: hacia una síntesis de su conocimiento, Vol. I. CONABIO-UNAM, México, 3-14.

Minelli A, Bonato L, Dioguardi R et al. (Ed) (2006): Chilobase: a web resource for Chilopoda taxonomy. http://chilobase.bio.unipd.it/ [accessed 10.X.2010]

Morón MA (1994) Taxonomía de artrópodos en México: pasado y futuro. Revista AIC 17: 9-14.

Navarrete-Heredia JL, Gómez-Rodríguez C, Newton AF (2006) Staphylinidae (Insecta: Coleoptera) of the Biología Centrali-Americana. Zootaxa 1251: 1-70.

Pocock RI (1895-1910) Chilopoda and Diplopoda. Biologia Centrali-Americana 14: 1-217. (http://www.sil.si.edu/DigitalCollections/bca/)

Schileyko A, Stagl V (2004) The collection of scolopendromorph centipedes (Chilopoda) in the Natural History Museum in Vienna: a critical re-evaluation of former taxonomic identifications. Annalen des Naturhistorischen Museums in Wien 105 B: 67-137.

Schileyko AA, Minelli A (1999) On the genus Newportia Gervais, 1847 (Chilopoda: Scolopendromorpha: Newportiidae). Arthropoda Selecta 7 (4): 265-299.

Selander RB, Vaurie P (1962) A gazetteer to accompany the "Insecta" volumes of the "Biologia Centrali-Americana”. American Museum Novitates 2099: 1-70. 
Shelley RM (1997) The holarctic centipede subfamily Plutoniuminae (Chilopoda: Scolopendromorpha: Cryptopidae) (Nomen correctum ex subfamily Plutoniinae Bollman, 1893). Brimleyana 24: 51-113

Shelley RM (2006) A chronological catalog of the New World species of Scolopendra L., 1758 (Chilopoda: Scolopendromorpha: Scolopendridae). Zootaxa 1253: 1-50.

Shelley RM, Chagas-Junior A (2004) The centipede genus Arthrorhabdus Pocock, 1891, in the western hemisphere: potential occurrence of A. pygmaeus (Pocock, 1895) in Belize (Scolopendromorpha: Scolopendridae: Scolopendrinae). Western North American Naturalist 64 (4): 532-537.

Verhoeff KW (1925) Chilopoda. In: Bronn HG (Ed) 1902-1925 Klassen und Ordnungen des Tier-Reiches, Vol. 5 (2). Akademische Verlagsgesellschaft, Leipzig, 539-666.

Würmli M (2005) Revision der afrikanischen Pselliodiden (Chilopoda: Scutigerida: Pselliodidae). Schubartiana 1: 3-8.

Würmli M (1973) Die Scutigeromorpha (Chilopoda) von Costa Rica. Über Dendrothereua arborum Verhoeff 1944. Studies on the Neotropical Fauna 8: 75-80. 